Article

\title{
Exploring Innovation Ecosystem from the Perspective of Sustainability: Towards a Conceptual Framework
}

\author{
Zheng Liu ${ }^{1,2, *}$ and Victoria Stephens ${ }^{1, *}$ \\ 1 Faculty of Business and Society, University of South Wales, Pontypridd CF37 1DL, UK \\ 2 Centre for Innovation and Development, Nanjing University of Science and Technology, Nanjing 210094, \\ China \\ * Correspondence: zheng.liu@southwales.ac.uk (Z.L.); victoria.stephens@southwales.ac.uk (V.S.)
}

Received: 30 May 2019; Accepted: 23 July 2019; Published: 25 July 2019

\begin{abstract}
With technology advancement, industrial revolution 4.0, businesses nowadays are in competition in terms of product, service and business model innovation. Meanwhile, the emergent socio-ecological crisis is making it increasingly important to identify the impact of business on environment and the society. To date, much literature has explored how sustainability might be achieved through firms' internal research and development, and supply chain collaboration. However, issues such as how different stakeholders including customers, partners, government, and universities can be involved, forming innovation ecosystem in a sustainable way is under-explored. This paper aims to provide connection between innovation and sustainability, through literature review and exploratory case studies. A conceptual framework is generated starting from firm/intra-firm level, to supply chain/inter-firm level, and towards ecosystem level. With emerging themes of innovation from sustainability perspective proposed, the framework can be enriched and validated through future empirical studies.
\end{abstract}

Keywords: sustainable innovation; innovation ecosystem; sustainability; innovation

\section{Introduction}

Business success is increasingly dependent upon innovation and sustainability. Innovation is related with knowledge creation and sharing activities within and between organizations. It features explorations and introductions of new products, new methods of production, new markets, new sources of supply, and new industry organizations [1]. The Internet of Things, big data, 3D printing, and other advanced technologies of the Fourth Industrial Revolution, increasingly reflect and enable the development of a sharing economy with features of creativity, participation of small firms, and society involvement [2].

At the same time, social and environmental impacts of production and economic activities are becoming increasingly important as companies are now considering sustainable features in their product innovation, process technology and supply chain. Through such approaches as reducing energy consumption, investing in recycling and engaging in community activities, companies' brand and image can better recognized by customers, which in return brings profit to the company in a sustainable way. Indeed, there is an increasing pressure on companies to be transparent in their performance related to such issues as carbon emissions, albeit with varying pressures leading to variation of disclosure strategies [3,4]. Beyond the ecological aspects, however, sustainability is often addressed through the Triple-Bottom-Line (TBL) framework, meaning that true sustainability sits at the intersection of economic (financial), environmental (ecological), and social aspects [5].

In a proactive way, considerations of these dimensions can be linked to new product and process design, enabling firms to respond to new sustainability pressures and challenges, while also taking 
advantage of attendant opportunities. Externally, supply management, ethical sourcing, and close customer relationship development can also generate innovation with impacts (and benefits) for both the institution and the wider community. Firms such as Boeing, Airbus, and Apple already conduct practices of innovation through an open system approach which combines knowledge resources of upstream and downstream organizations in their supply chain [6]. Beyond their supply chain partners, government, industrial association, universities and wider society can also be actively engaged, altogether forming an innovation ecosystem, with the features of multi-level, multi-modal, multi-nodal, multi-lateral systems, and with features of co-existence, co-evolution, co-specialization, and co-opetition [7]. It is believed that innovation has expanded from Mode 1 university-based knowledge linear model, to Mode 2 [8] university-industry non-linear model, and now to Mode 3 [7] known as the university-industry-government-civil society non-linear model 'quadruple helix model' [7]. With civil society involved, the concept of sustainable innovation starts to emerge in this complex dynamic ecosystem.

Research on sustainable innovation been conducted recently, however, its business model as yet remains underexplored [9]. Furthermore, the concept of sustainable innovation expands from corporate social responsibility to consider the dynamic network, which is central in the context of a new industry era of innovation, sharing economy, collective learning, and society involvement. Therefore, it is important to understand its new meaning, and identify research areas that will shape a meaningful research agenda.

Driven by academic interest and industry requirement, this paper aims to explore the issue of innovation in terms of sustainability. Specifically, the following three questions will be answered. (1) What are the key areas of sustainable innovation at the intra and inter-firm levels, in theory and practice? (2) What are the emerging issues of sustainable innovation in the context of innovation ecosystem, in theory and practice? (3) What are the future research areas of sustainable innovation at the ecosystem level?

\section{Literature Review}

To explore the dynamics of technological transition towards sustainability and resilience, multi-level perspective framework (MLP) is used as an analytical tool, which divide socio-technical system in to landscape (macro-level), regimes (meso-level) and niches (micro-level) [10]. For the scope of this research as shown in Figure 1, analysis starts with intra-firm and inter-firm sustainable innovation, which focuses on micro-level and meso-level product, service, and process innovation from theories of operations management and supply chain. They can be the knowledge building blocks to eventually reaching the unknown issues at the more macro level of ecosystem, involving board stakeholders' participation and contribution. Accordingly, extant literature can be reviewed from intra-firm and inter-firm levels, and ecosystem.

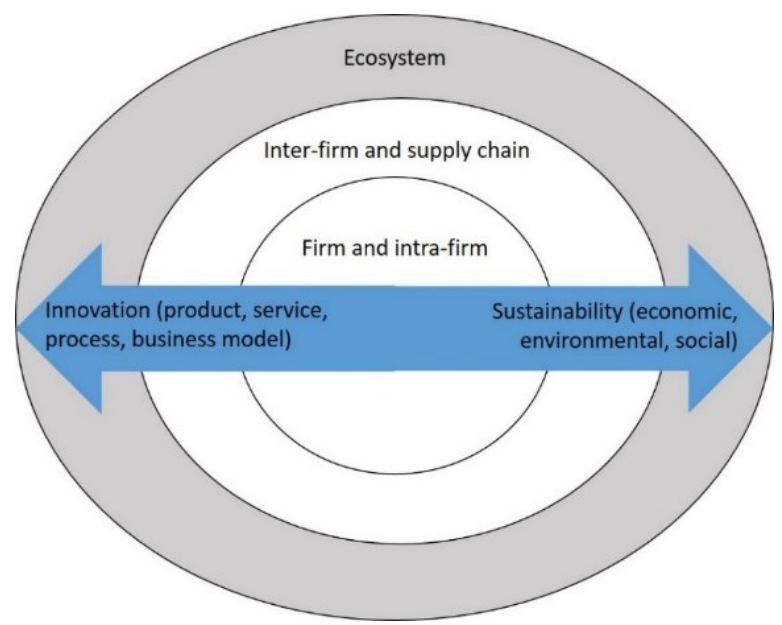

Figure 1. Research scope. 


\subsection{Intra-firm and Inter-firm Levels}

Inside companies, innovation is related to product and service design, as one important decision-making area of operations. The process involves transforming resources, such as design and technical staff, equipment, and transformed resources such as information, in order to deliver new products and/or services with clear specification. Sustainability is closely connected with product and service innovation, including recyclability of materials, energy consumption, waste material generation, and process technology in terms of waste and product disposal, noise pollution, fume and emission pollution and energy efficiency [11]. Environmental technologies including pollution prevention and control, and environmental management systems are considered as hard and soft technology management [12]. At the firm and intra-firm level, sustainable innovation interacts with products, processes, services and business models [13]. In particular, from a sustainability perspective, it might be agreed that innovation in terms of business models is imperative to transitioning towards sustainable consumption and production [14] regardless of the ongoing debates about the appropriateness of continued economic growth [15] or alternative perspectives on sustainable development and the appropriate governance modes for its achievement [16].

The link between sustainable innovation and supply chain management has been emphasized on the basis that a requirement to be able to assess and improve the sustainability impacts of a product across its lifecycle inevitably requires input and contribution from the product's full supply chain, which likely exists outside of the full control of the focal company [17]. Isaksson et al. [18] emphasized that a greater orientation towards a supply chain/management perspective can lead to greater potential for innovation in the name of sustainable development, which may be seen to be reinforced by a perspective of supply chain as a 'knowledge alliance' [19], on the assumption that knowledge increase is an enabler of innovations for the benefit of sustainable development.

This builds on previous acknowledgement of the role of supply chain management in the success of traditional (i.e., non-sustainable) new product development efforts [20]. Carvalho and Barbieri [17] (p. 147) therefore define sustainable innovation as 'the introduction of products, production processes, management or business methods, new or significantly improved, that bring economic social or environmental outcomes, considering the supply chain and compared with relevant alternatives'. In more recent years, efforts have emerged to more systematically and formally codify the concept of sustainable supply chain innovation (SSCI) [21,22]. Gao et al. [22] suggest that 'sustainable supply chain innovation' has emerged from the root of supply chain innovation (SCI), which can be defined as an integrated change from incremental to radical changes in the product, process, marketing, technology, resource and/or organization which are associated with all the related parties, covering all related functions in supply chain and creating value for all stakeholders' [21] (p. 3497).

Therefore, in the context of supply chain management, sustainable innovation may be seen as complex and multi-faceted, reflecting numerous categories or 'types' of innovation (product, process, organizational structure and business models) [21] which are variously intersected with the multiple inter-firm, upstream and downstream processes that constitute supply chain management (including for example, 'make', 'source', 'deliver', 'retail') [23,24]. Gao et al. [22] codifies the breadth of these intersections in their conceptual framework of SSCI. This is then further detailed by the multi-dimensional performance indicators of sustainability that expand beyond traditional economic performance indicators of innovations (such as costs, return on investment or market share) to include social and environmental performance indicators (such as waste reduction, recyclability, health and safety etc.). For example, in the context of food supply chains, four sustainability criteria have been codified to classify sustainable new food product development: developing a healthier product (e.g., reducing preservatives); designing for the environment (i.e., selecting materials/components that have minimum impact over entire life); design for extending lifecycle (e.g., through use of specific long-lasting materials) and design with sustainable materials (e.g., adopting recycled materials) [24].

The implementation of innovative strategies for enhancing sustainability across supply chains is driven by both internal and external motivations and incentives (such as government regulations, 
customer requirements, competitive advantage and the personal values of managing directors and/or employees) [25-27]. These strategies may been seen as 'reactive' or 'proactive' [25] and thus as 'incremental' or 'radical' in their innovativeness, respectively [17,26]: incrementally innovative strategies for enhancing sustainability in the supply chain may involve supplier management and development approaches which seek to improve the sustainability (environmental/social) performance of existing supply chain structures/products/processes through managing risks and performance levels across the supply chain; radically innovative strategies might involve the proactive development of new sustainable products which requires the development of new relationships and new supply chain structures $[25,28]$. In this regard, for both incremental and radical innovations for sustainable supply chain management, the importance of relationships and collaboration with supply chain partners has been emphasized [29].

The ability to manage relationships and develop partnerships for sustainable innovations in supply chains has been identified as one of a series of 'dynamic capabilities' that are seen as an essential pre-requisite for innovating for sustainability in supply chain management [30]. Through a case study of an Italian SME in the food industry, Leon-Bravo et al. [24] therefore linked certain dynamic capabilities to certain types of innovation (incremental or radical). The authors found that while DCs such as knowledge assessment (the ability to assess knowledge for its quality) and reflexive control (the ability to constantly monitor the performance of the supply chain in terms of its required functionality) were necessary for incremental innovation, partner development (developing supply chain partners' capabilities through knowledge sharing, joint programs), supply chain reconceptualization (the ability to re-design supply chain architecture as required), co-evolving (developing and implementing new capabilities through collaboration), and knowledge acquisition (the ability to acquire knowledge already possessed by other supply chain partners) were necessary for radical innovation.

In this regard, the literature has highlighted the role of the focal company (the company that rules or governs the supply chain, or has direct contact with the customer, or is the brand-owner [25] as a source of diffusion of innovation across their supply chain: Carvalho and Barbieri [17] described the focal company as an 'innovation inductor'. Their work builds on Van Bommel [28] who suggested that the 'innovation power' of a focal company mediates the relationship between external drivers of sustainability and the implementation of sustainable supply chain strategies [25]. The 'innovation power' of the focal company is composed from the 'innovation characteristics' of the focal firm (such as cooperation between departments, learning and adapting, possibility for experimenting, and results driven) and the 'cooperative characteristics' of the supply chain (such as level of trust, reputation, joint programs and cooperative information sharing systems).

\subsection{Ecosystem Level: Open Innovation, Innovation Ecosystem, Triple/Quadruple Helix}

While intra and inter-firm research can be directly seen in the literature of product innovation, and supply chain, the concept of ecosystem can be explored through open innovation, business ecosystem, innovation ecosystem, and triple helix theories.

While traditional product and process innovation is conducted within large firms or through formal supply chain partners, known as the close innovation, the concept of open innovation emerges as firms use external and internal ideas to advance their technology, breaking down company boundaries towards knowledge sharing for product and service development [31]. Using ecological metaphors, Moore developed the concept of business ecosystem, and defined it as 'an economic community supported by a foundation of interacting organizations and individuals - the organisms of the business world. The economic community produces goods and services of value to customers, who are themselves members of the ecosystem. The member organisms also include suppliers, lead producers, competitors, and other stakeholders. Over time, they co-evolve their capabilities and roles and tend to align themselves with the directions set by one or more central companies. Those companies holding leadership roles may change over time, but the function of ecosystem leader is valued by the community because it enables members to move toward shared visions to align their investments and to find 
mutually supportive roles' [32] (p. 26). This has extended the formal supply chain towards a broad network of stakeholders and indirect business collaborator in a dynamic and interdependent form. While supply chain theories focus on industry and value chain level, the concept of business ecosystem refers to the evolution of suppliers, lead producers, competitors, and other stakeholders, going through existing collaboration, through expansion, convergence and renewal stages [33]. This dynamic process can help companies to rethink about its business structure, sustainability and natures of collaboration in forming and sustaining both new industry and established sectors.

From a knowledge management perspective, innovation ecosystem consists of economic and non-economic agents and relations including technology, institutions, sociological interactions, and culture $[34,35]$. However, details of organizational structure of innovation ecosystem and its development process are not explored enough in current literature. It can be seen from the meanings and scope of ecosystem, supply chain is a formal inter-firm connection within a well-defined industry sectors or product, whereas open innovation involves more informal and indirect relations within a certain industry sector, yet sometimes product being uncertain. Business ecosystem extend supply chain towards general stakeholder involvement, with the outcomes of expanding, converging and renewing to a new industry or value chain. Innovation ecosystem focuses on knowledge and IP creation, sharing and exchange, sometimes not necessarily result in tangible outcomes such as a product or value chain. These issues overlap, helping to generate a holistic view towards ecosystem, and its interaction with sustainability from economic, environmental and social perspectives. Ecosystem also overlaps with alliance and cluster. However, its structure is an alignment of 'multilateral set of partners that need to interact in order for a focal value proposition to materialize' [36] (p. 42).

Recent theories of triple helix investigates the non-linear connection among university, industry and government for knowledge creation and sharing, where industry acts as the source of production, government provides regulations, stability and rules of play, and universities are the suppliers of new knowledge and technology $[37,38]$. Based on triple helix, a further element of innovation-media-based and culture-based public/civil society/intermediary organizations is later on identified, altogether known as the quadruple helix model [39]. With the introduction of civil society and media/culture based intermediary, sustainable innovation involving society becomes a new research topic in the quadruple helix and ecosystem environment. However, currently there is limited understanding of soft side issues of quadruple helix ecosystem, such as trust and relationship building [40]. Such soft factors are deemed to be integral to the partnership and cooperation strategies that can enable fundamental resource sharing within a truly open innovation ecosystem context, such as a Smart City [41].

Apart from the helices, industrial association plays an important role in the ecosystem, helping firms to develop capability [42]. Social innovation studies provide another stream of literature, emphasizing the role of product and process innovation with social purpose [43], and developing social entrepreneurship [44]. Apart from universities and customers' involvement, firms can work with NGOs and intermediaries to strengthen open innovation performance [45]. At the regional level, studies explore the relationship between environmental sustainability and smart cities, combining digital technology innovation, knowledge management, economic efficiency, creativity, sustainability, and long-term urban planning [46,47]. A new economic culture emphasizing knowledge and learning shall be involved with the emergence of knowledge and smart cities [41,48]. Carayannis and Campbell [49] suggested that eco-innovation and eco-entrepreneurship should be highlighted in a broader understanding of innovation, with industry, firms, economic system; state, government, political system; academia, universities, higher education system; media-based and culture-based public; and natural environmental and natural environments of society contexts, proposed as the new framework of quintuple helix.

\section{Research Methodology}

The aim of this paper is to investigate the emerging phenomenon of sustainable innovation, in the context of innovation ecosystem and quadruple helix environment. A systematic literature review is 
beyond our research scope. Instead, deep analysis was taken into the key theoretical work related to innovation and sustainability, and focus on recently published literature review papers which cover sustainable innovation, defined as 'transparent, interactive process by which societal actors and innovators become mutually responsive to each other with a view on the acceptability, sustainability and societal desirability of the innovation process and its marketable products' [50] (p. 9). Based on this, the research explores broader meanings and emerging issues which can link innovation and sustainability. Thus, key issues are summarized from firm/intra-firm level, supply chain/inter-firm level and ecosystem level, which provides the key building blocks of our conceptual framework.

Current literature clearly shows the interaction of innovation and sustainability at the firm and supply chain level through product and process innovation. However, sustainable innovation on the ecosystem level, combining the features of openness, co-evolution among university, industry, government and civil society is not clear yet. In fact, empirical studies on quadruple helix innovation have just begun to emerge [40]. As a new concept, the implementation of responsible innovation in the business context is still limited [51].

Thus, to enrich the framework, exploratory case studies were conducted. As Eisenhardt [52] states, case studies can explain details of current phenomenon. Yin [53] suggests that case study method be applied to explain, describe, illustrate, explore and for meta-evaluation. To further understand the interaction of innovation and sustainability in practice, three case companies were selected, based on the criteria. (1) These firms are recognized for their good practice of innovation, as well as sustainability/CSR; (2) They have strong internal research and development capability, and collaborate with a range of external partners; (3) They initiate open innovation platforms with external resources, extending supply chain relationship towards ecosystem; (4) Data related to their innovation and sustainability practice can be assessed either from the companies' website or published resources; (5) There is a combination of product innovation, stakeholder engagement, and open innovation from the case companies, which can potentially be implemented in other companies; (6) Though companies may be from different sectors, findings of their practice activities can be extended to general issues of sustainable innovation, along with the themes identified by existing literature. Table 1 shows details of the companies' information.

Table 1. Case company information.

\begin{tabular}{ccc}
\hline Company & Research Focus & Source of Data \\
\hline Heineken & Supply chain; Open innovation & Company website/report [54] \\
\hline BMW & $\begin{array}{c}\text { Supply chain; Product sustainability; } \\
\text { Open innovation }\end{array}$ & Company website/report [55] \\
\hline P\&G & $\begin{array}{c}\text { Firm/intra-firm; Supply chain; Open } \\
\text { innovation; Innovation ecosystem }\end{array}$ & $\begin{array}{c}\text { Company website [56], Published } \\
\text { papers [57,58] }\end{array}$ \\
\hline
\end{tabular}

For the purpose of exploratory case study, data were collected from secondary sources such as published paper, companies' websites, and CSR and sustainability reports, following activities, projects, products and processes. They were then categorized into firm/intra-firm level, meaning sustainable innovation within a single company or different sites of the same MNE; inter-firm level, meaning sustainable innovation between the focal firm and its supply chain partners; and ecosystem level, meaning sustainable innovation occurring beyond the formal supply network, involving users, universities, government, and other indirect partners. Through content analysis, data at each level were coded and positioned according to its connection with the three pillars of the triple-bottom-line, economic, environmental and social sustainability. For example, ethical supply chain management and fair trade was positioned as inter-firm social sustainability; improving ecological features of the product through internal research and development was a firm/intra firm environmental sustainable innovation practice. Then a comparison was made between case findings and literature, which can 
generate a conceptual framework, combining innovation and sustainability with key players (enablers) and KPIs at the ecosystem level.

Considering future research based on this paper, eventually aiming to build up linkage among innovation ecosystem and sustainability, we also propose a research agenda (Figure 2) containing three major phases of the research project: theory building and exploratory case studies (this paper), theory building and main case studies (future research), and theory testing and validation (future research). This paper is the first step, adopting qualitative method with exploratory case studies to identify emerging issues of sustainable innovation at different levels, and proposing framework. The second step is theory building with main case studies, to reveal on-going issues in business and enrich the previous framework. Finally, quantitative methods will be adopted for theory testing and validation.

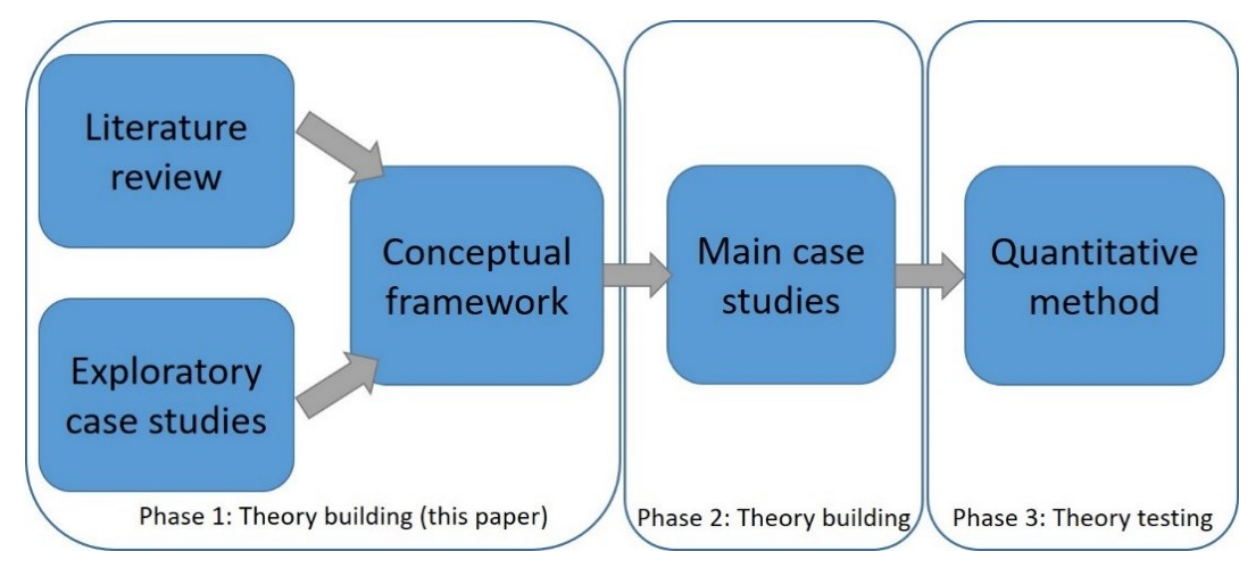

Figure 2. Research process.

\section{Findings and Discussion}

Literature review suggests that at the firm and inter-firm levels, product, service and process sustainable innovation studies are already mature, as part of operations and supply chain management theories. At the ecosystem level, open innovation highlights knowledge creation across companies with a clear objective, such as a product design, whereas business ecosystem and innovation ecosystem involves uncertainty of the innovation output, while the system itself is an extension and improvement of existing collaboration. Triple helix and quadruple helix theories provide models of non-linear innovation, with university, industry, government and society interaction. In particular, with society and environment highlighted in the recent quintuple helix theory, innovation is closely linked to sustainability. However, as new theories, details are not clear, and there is a need for more empirical studies. Thus, to further understand detailed meaning and new issues of sustainable innovation, we investigated three companies, which have launched sustainable innovation related programs either at the network or society level.

\subsection{Exploratory Case One-Heineken}

At the firm/intra-firm level, Heineken considers using renewable energy (solar and wind energy), innovation into natural material and product, reducing waste and improving quality through improving operations technology (e.g., storing). To promote shareholder interaction, it launched the project of 'Innovators Brewhouse', as connected innovation space, open to entrepreneurs, inventors, universities, suppliers and individuals. The aim is to collectively find solutions to Heineken challenges through invention and shared development. These challenges include sustainability (such as packaging technology), brewing and distribution, technology, product and ingredients. Through innovation, Heineken can build knowledge resources, expanding innovation ecosystem and co-creating with partners and the society. 


\subsection{Exploratory Case Two-BMW}

In terms of product design at firm/intra-firm level, electric mobility is currently BMW's main strategic focus. For example, the company develops battery technology in Germany, the US and China, forming local supply chains. For environmentally sustainable purpose, BMW conducts research on innovative tank and refueling technologies combined with a new fuel cell cooling concept. BMW works with global supply chain partners on new technology and product research and development. For example, BMW's research institute in Shanghai focuses on digital and driverless technology, through collaboration with various local experts forming innovation ecosystem. In addition, open innovation offers the company opportunities to increase its product pipeline and to integrate external ideas. One of its approaches is the Co-Creation Lab, an open platform where the public can share ideas and opinions about the future of cars and co-create products and services. The lab hosts innovation competitions such as the BMW Group Interior Design Contest that challenged the crowd to come up with innovative ideas to personalize the interior of cars. Through this way, BMW can better understand customers' requirements, while getting concepts for design and promoting a good image to the society.

\subsection{Exploratory Case Three-PEG}

$P \& G$ as a large consumer goods company has been known as innovative. For sustainable purpose, it has research into renewable energy, recycled material, designing products while maximizing the conservation of resources. With business scale reaching the globe, it also established centralized research institute (e.g., health care research center) to integrate global knowledge resources. The team studies consumers' top needs for new product innovation. Internally, the technology of one product can be transferred to another product, as a way of sharing technology and reducing cost continuously. The company culture encourages learning across functions. Apart from in-house innovation, P\&G collaborate closely with its major supply chain partners, through secured web platform of data sharing. Beyond formal supply chain, $P \& G$ also initiates innovation ecosystem by launching 'Connect + Develop' model. This is an open platform engaging external partners and individuals to contribute new technologies and solutions. Open innovation not only triggers new ideas for P\&G's products, but also facilitates downstream activities such as commercialization and customer relationship management. The online portal is now also used as an IP exchange platform, as part of service development. With the innovation ecosystem expanding, it is now reaching collaboration with university, government, private consultants and other resources, demonstrating a sustainable innovation model.

\subsection{Discussion}

While literature highlights social innovation, user safety, eco-efficiency, and government policy, industry practice suggests open platform, shareholder engagement, cultural, trust relationship and public/social innovation. The above three exploratory cases show that at firm and intra-firm level, internal research and development, global research resource integration, customer studies are major ways of sustainable innovation. At the supply chain level, formal collaboration based on long-term trust continuously generates new product and value. Building relationships with local experts can identify new opportunities of learning and growth. Open innovation is an effective way for firms to further engage with the society, and absorb knowledge continuously. With emphasis on sharing and coevolution, industry can work with university, government and users to solve problems together. A transformation from manufacturing towards service development is also a trend for continuous generation of value, knowledge and market. Combining literature and industry observation, we summarized sustainable innovation related activities at firm, supply chain, and ecosystem levels, along with the triple-bottom-line framework of sustainability (Table 2). 
Table 2. A summary of sustainability innovation activities at different levels.

\begin{tabular}{|c|c|c|c|}
\hline Sustainability & Firm Level Innovation & $\begin{array}{l}\text { Supply Chain and Inter-firm Level } \\
\text { Innovation }\end{array}$ & Ecosystem Level Innovation \\
\hline Economic sustainability & $\begin{array}{l}\text { Improving business model to enable } \\
\text { sustainable innovation; } \\
\text { Conducting internal research and } \\
\text { development to improve ecological features of } \\
\text { product and materials; } \\
\text { Adopting technology for internal waste } \\
\text { management and cost reduction; } \\
\text { Promoting a culture of innovation internally; }\end{array}$ & $\begin{array}{l}\text { Retaining long-term relationship with } \\
\text { existing suppliers; } \\
\text { Transferring knowledge and technology } \\
\text { transfer from universities to industry; } \\
\text { Developing trust and secured } \\
\text { relationship with supply chain partners; } \\
\text { Adopting new technology and process } \\
\text { for continuous innovation; } \\
\text { Learning and sharing knowledge with } \\
\text { supply chain partners; }\end{array}$ & $\begin{array}{l}\text { Providing open platform to exchange } \\
\text { knowledge with external sources; } \\
\text { Collaborating with SMEs and individuals; } \\
\text { Engaging with government for policy, } \\
\text { infrastructure, and funding support; } \\
\text { Seeking; } \\
\text { Collaborating with social enterprises and } \\
\text { industry associations; } \\
\text { Moving from manufacturing to service for } \\
\text { business continuity }\end{array}$ \\
\hline Environmental sustainability & $\begin{array}{l}\text { Improving ecological feature of product, } \\
\text { material and service; } \\
\text { Adopting sustainable production at firm level } \\
\text { (e.g., recycling, reducing waste and packaging, } \\
\text { new energy); }\end{array}$ & $\begin{array}{l}\text { Adopting sustainable production } \\
\text { standards along the supply chain; } \\
\text { Selecting new suppliers according to } \\
\text { sustainable and environmental } \\
\text { performance; } \\
\text { Adopting new technology to reduce } \\
\text { carbon emission along the supply chain; } \\
\text { Re-design the supply network to achieve } \\
\text { sustainability; }\end{array}$ & $\begin{array}{l}\text { Developing solutions related to environmental } \\
\text { issues collaboratively with SMEs, individuals } \\
\text { and users through open platform; } \\
\text { Researching on green technology through } \\
\text { collaboration with universities and research } \\
\text { institutions; }\end{array}$ \\
\hline Social sustainability & $\begin{array}{l}\text { Considering user safety in product and service } \\
\text { design; } \\
\text { Engaging with community; } \\
\text { Considering users' need at early stages of } \\
\text { product and service design; } \\
\text { Combining social innovation with CSR; }\end{array}$ & $\begin{array}{l}\text { Developing ethical sourcing standards } \\
\text { along the supply chain; } \\
\text { Developing customer relationship and } \\
\text { improving user experience; } \\
\text { Considering fair trade for new supplier } \\
\text { development and long-term ethical } \\
\text { supply chain; }\end{array}$ & $\begin{array}{l}\text { Involvement with a broad range of shareholders } \\
\text { including NGOs and intermediaries; } \\
\text { Collaborating with social enterprises; } \\
\text { Using open innovation approaches and social } \\
\text { media to encourage user contribution at product } \\
\text { design and commercialization stages; } \\
\text { Expanding collaboration network to universities } \\
\text { and government }\end{array}$ \\
\hline
\end{tabular}


So far, the theory and practice explored have demonstrated links between innovation and sustainability at the firm and supply chain levels. However, at the innovation ecosystem level, there are still research gaps. Details of how sustainable innovation can be formed, developed and improved are as yet unknown. Exploratory case studies show firms improving ecological feature of product and service, reducing carbon footprint though improving internal operations, and collaborating with supply chain partners. This can be the practical meaning of sustainable innovation at the firm and supply chain level. At the ecosystem level, the concept of sustainable innovation means much more. Industry practice suggests co-creating knowledge, stakeholder engagement, working together with partners and customers for solutions related to technology, product development and environmental sustainability. In this way, sustainability can be a driving force of innovation and business changes, whereas the approaches of innovation contributes to sustainability, providing new agenda of economic, social and environmental issues. As illustrated in Figure 3, the two dimensions interact together, forming a feedback loop in a dynamic way. During the interaction, the key players and enablers include industry (companies, suppliers, competitors etc.), university, research and development institutes, government, users and NGOs. The outcome is sustainable innovation ecosystem in terms of long-term product, service, process, business model, and network development.

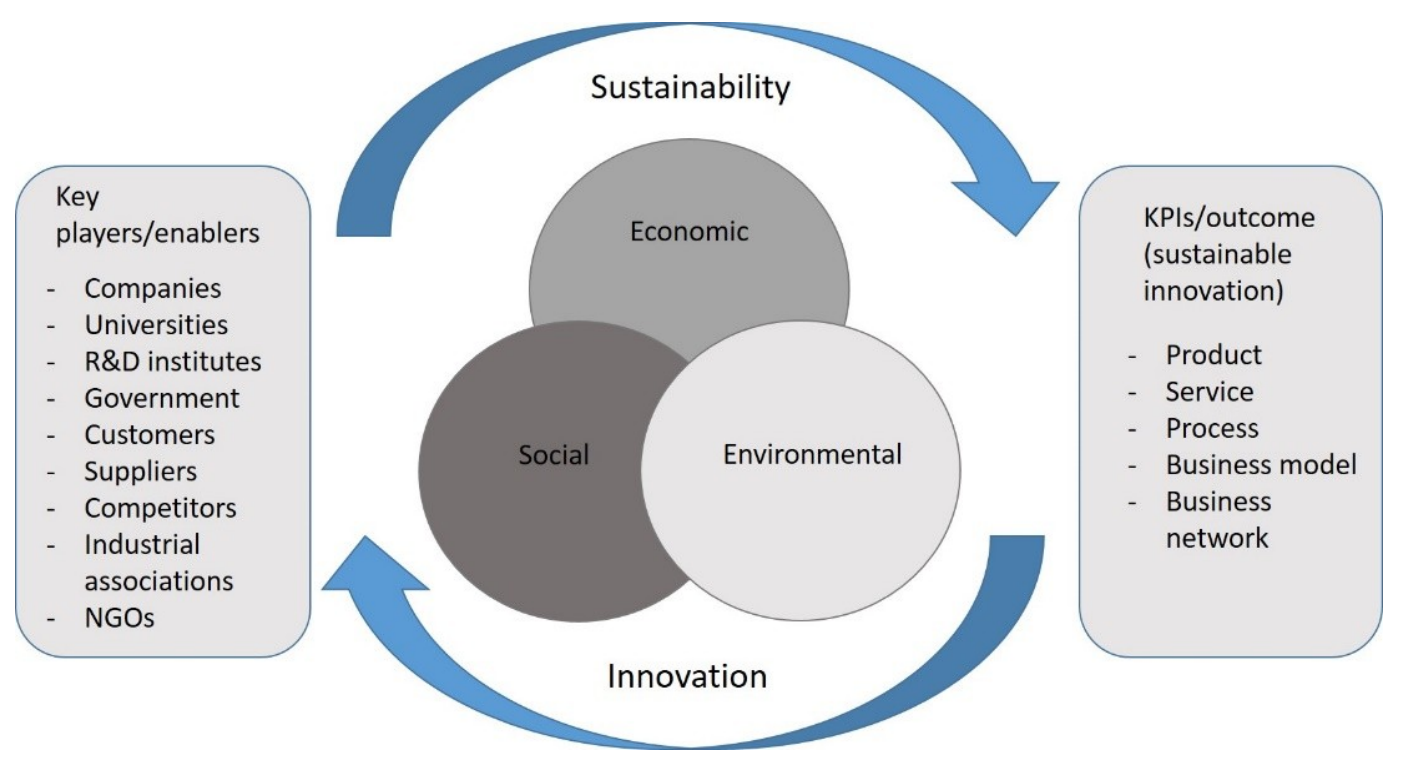

Figure 3. A conceptual framework of sustainable innovation.

Situating these findings in terms of existing theoretical considerations, they suggest much potential for extending and developing our understanding of how organizations might fruitfully contribute to addressing the socio-ecological crisis that the planet is currently facing [59]. It may be tentatively suggested at this stage that sustainable innovation at the ecosystem level re-iterates the importance of stakeholder (particularly consumer) engagement [60] from multiple perspectives: first, in terms of legitimating firm activity through greater understanding of customer desires which are increasingly related to sustainability issues (as seen in BMW) and to facilitate commercialization and customer relationship management (as seen in $P \& G$ ); and second, in terms of increasing stakeholder access to firms, towards holding them accountable for their great power and potential to both harm and help socio-ecological conditions through their operations. This similarly may contribute to discussions regarding the (changing) roles and responsibilities in society of large firms such as Heineken, BMW and $P \& G$ in the Anthropocene.

Approaches to sustainable innovation at the ecosystem level may also facilitate a more democratic approach to defining and articulating the sustainability impacts of an organization's operations from a multi-stakeholder perspective, thereby recognizing the multi-faceted and normative nature of 
sustainability [61]. However, in recognizing critical perspectives on sustainability, it should perhaps also be considered the extent to which approaches such as BMW's 'Co-Creation Lab', P\&G's 'Connect and Develop' platform, and Heineken's 'Innovators Brewhouse', work to further propel the voice of the most powerful stakeholders, and fail to capture sustainability perspectives and impacts as experienced by those (customers/suppliers) at the 'bottom of the pyramid' [62,63]. Thus, from our conceptual framework, we have also identified some emergent issues, which are tentatively proposed as important areas for future research.

Open innovation is regarded as an effective way to achieve sustainable innovation through collaboration and stakeholder involvement. It is built upon a well-defined industry sector or product. From industry observation, open platform can be initiated by large firms which already have resource such as recognized brand and market. They can easily attract potential external partners for knowledge exchange. However, the role of SMEs is unclear, especially in the early stage of innovation ecosystem. So far innovation research on SMEs still has been paid little attention, particularly in less developed countries [64]. Can SMEs play a more active role in the ecosystem? How can SMEs learn and share knowledge, expanding and achieving sustainable development? Can SMEs form a business ecosystem, without leading large firms? These can potentially be new topics of sustainable innovation in terms of social and economic sustainability.

The same situation applies to less developed countries and regions where there are no leading firms, or knowledge resources such as universities. In this case, can society or government contribute to the forming of an innovation ecosystem? In some cases, legal frameworks (e.g., environmental protection, ethical code of conduct) are not matured, which may stop firms from considering innovation in the context of sustainability. The study into policy management can enrich the triple and quadruple helix, and even the latest quintuple helix theory.

In the context of innovation ecosystem, theory suggests that government, industry, university, and civil society can interact to create knowledge; however, empirical studies are needed to explore the details. In particular, research should focus on the structure, component, dynamic process, and key performance indicator of sustainable innovation. Other issues such as the impact of culture on sustainable innovation, and the soft side of management such as trust relationships can also be potential research areas.

\section{Conclusions}

With the aim of understanding innovation from a sustainability perspective, this paper contributes to the theory of innovation and sustainability in the context of ecosystem and quadruple helix. Through a review of existing literature and industry case studies, key decision-making areas are identified that exist at the firm, inter-firm and ecosystem levels (Table 2). The conceptual framework (Figure 3) suggesting the interaction between innovation and sustainably as a dynamic process involving key players to deliver the outcomes. Based on the framework, further research areas are proposed. Apart from enriching innovation theory, these findings also advance the concept of triple bottom line by linking it with emerging issues of innovation, with a broad range of stakeholder involvement.

There are some limitations of our study. Firstly, it is an initial theory investigation, not a systematic literature review of innovation and sustainability. Secondly, industry review and secondary case studies constructed from online resources can only help to develop an initial conceptual framework, not an in-depth empirical reality of business practice. Similarly, the insight is based on three exploratory company cases, which cannot represent the diversity of industry sectors in the complex innovation ecosystem. Therefore, it is proposed that future research should investigate a broad range of industry sectors, taking different players such as government, universities and civil society into account. In-depth main case studies and quantitative methods can be used to further improve and validate the framework. 
Author Contributions: Conceptualization, Z.L. and V.S.; Methodology, Z.L. and V.S.; Formal Analysis, Z.L. and V.S.; Investigation, Z.L. and V.S.; Resources, Z.L. and V.S.; Writing-Original Draft Preparation, Z.L. and V.S.; Writing-Review and Editing, Z.L. and V.S.

Funding: This research was funded by the Faculty of Business and Society Dean's Research Fund, University of South Wales, UK.

Conflicts of Interest: The authors declare no conflict of interest.

\section{References}

1. Schumpeter, J.A. The Theory of Economic Development; Harvard University Press: Cambridge, MA, USA, 1934.

2. Park, H.S. Technology convergence, open innovation, and dynamic economy. J. Open Innov. Technol. Mark. Complex. 2017, 3, 24. [CrossRef]

3. Herold, D.M.; Lee, K.H. The influence of internal and external pressures on carbon management practices and disclosure strategies. Australas. J. Environ. Manag. 2018, 26, 63-81. [CrossRef]

4. Herold, D.M.; Farr-Wharton, B.; Lee, K.H.; Groschopf, W. The interaction between institutional and stakeholder pressures: Advancing a framework for categorizing carbon disclosure strategies. Bus. Strategy Dev. 2019, 2, 77-90. [CrossRef]

5. Elkington, J. Towards the sustainable corporation: Win-win-win business strategies for sustainable development. Calif. Manag. Rev. 1994, 36, 90-100. [CrossRef]

6. Zeng, D.; Hu, J.; Ouyang, T. Managing innovation paradox in the sustainable innovation ecosystem: A case study of ambidextrous capability in a focal firm. Sustainability 2017, 9, 2091. [CrossRef]

7. Carayannis, E.G.; Campbell, D.F.J. Mode 3: Meaning and implications from a knowledge systems perspective', in Knowledge creation, diffusion, and use in innovation networks and knowledge clusters. In A Comparative Systems Approach across the United States, Europe and Asia; Elias, G.C., Campbell, D.F.J., Eds.; Praeger: Westport, CT, USA, 2016; pp. 1-25.

8. Gibbons, M.; Limoges, C.; Nowotny, H.; Schwartzman, S.; Scott, P.; Trow, M. The New Production of Knowledge, the Dynamics of Science and Research in Contemporary Societies; Sage: London, UK, 1994.

9. Boons, F.; Ludeke-Freund, F. Business models for sustainable innovation: State-of-the-art and steps towards a research agenda. J. Clean. Prod. 2013, 45, 9-19. [CrossRef]

10. Geels, F.W. Technological transitions as evolutionary reconfiguration processes: A multilevel perspective and a case-study. Res. Policy 2002, 31, 1257-1274. [CrossRef]

11. Slack, N.; Brandon-Jones, A.; Johnston, R. Operations Management, 7th ed.; Pearson Education Limited: London, UK, 2013.

12. Klassen, R.D.; Whybark, D.C. Environmental management in operations: The selection of environmental technologies. Decis. Sci. 1999, 30, 601-631. [CrossRef]

13. Schiederig, T.; Tietze, F.; Herstatt, C. Green innovation in technology and innovation management: An exploratory literature review. RD Manag. 2012, 42, 180-192. [CrossRef]

14. Lüdeke-Freund, F. Towards a conceptual framework of 'business models for sustainability'. In Knowledge Collaboration E Learning for Sustainable Innovation: 14th European Roundtable on Sustainable Consumption and Production (ERSCP) conference and the 6th Environmental Management for Sustainable Universities (EMSU) conference; Wever, R., Quist, J., Tukker, A., Woudstra, J., Boons, F., Beute, N., Eds.; Delft University of Technology: Delft, The Netherlands, 2010.

15. Boons, F.; Montalvo, C.; Quist, J.; Wagner, M. Sustainable innovation, business models and economic performance: An overview. J. Clean. Prod. 2013, 45, 1-8. [CrossRef]

16. van Zeijl-Rozema, A.; Cörvers, R.; Kemp, R.; Martens, P. Governance for sustainable development: A framework. Sustain. Dev. 2008, 16, 410-421. [CrossRef]

17. De Carvalho, A.P.; Barbieri, J.C. Innovation and sustainability in the supply chain of a cosmetics company: A Case study. J. Technol. Manag. Innov. 2012, 7, 144-156. [CrossRef]

18. Isaksson, R.; Johansson, P.; Fischer, K. Detecting supply chain innovation potential for sustainable development. J. Bus. Ethics 2010, 97, 425-442. [CrossRef]

19. Zhang, D.; Wang, C.H.; Zheng, D.; Yu, X. Process of innovation knowledge increase in supply chain network from the perspective of sustainable development. Ind. Manag. Data Syst. 2018, 118, 873-888. [CrossRef] 
20. Van Hoek, R.; Chapman, P. From tinkering around the edge to enhancing revenue growth: Supply chain-new product development. Supply Chain Manag. Int. J. 2006, 11, 385-389. [CrossRef]

21. Tebaldi, L.; Bigliardi, B.; Bottani, E. Sustainable supply chain and innovation: A review of the recent literature. Sustainability 2018, 10, 3946. [CrossRef]

22. Gao, D.; Xu, Z.; Ruan, Y.Z.; Lu, H. From a systematic literature review to integrated definition for sustainable supply chain innovation (SSCI). J. Clean. Prod. 2017, 142, 1518-1538. [CrossRef]

23. Supply Chain Council. Supply Chain Operations Reference Model; Version 10.0; Supply Chain Council, Inc.: Cypress, CA, USA, 2010.

24. León-Bravo, V.; Caniato, F.F.A.; Moretto, A.; Cagliano, R. Alcass: Innovation for sustainable supply chains for traditional and new Products. In Organizing Supply Chain Processes for Sustainable Innovation in the Agri-Food Industry; Emerald Group Publishing Limited: Bingley, UK, 2016; Volume 3, pp. 31-57.

25. Seuring, S.; Muller, M. From a literature review to a conceptual framework for sustainable supply chain management. J. Clean. Prod. 2008, 16, 1699-1710. [CrossRef]

26. Walker, H.; Jones, N. Sustainable supply chain management across the UK private sector. Supply Chain Manag. Int. J. 2012, 17, 15-28. [CrossRef]

27. Cagliano, R.; Worley, C.G.; Caniato, F.F.A. The challenge of sustainable innovation in agri-food supply chains. In Organizing Supply Chain Processes for Sustainable Innovation in the Agri-Food Industry; Emerald Group Publishing Limited: Bingley, UK, 2016; Volume 3, pp. 1-30.

28. Van Bommel, H.W.M. A conceptual framework for analyzing sustainability strategies in industrial supply networks from an innovation perspective. J. Clean. Prod. 2011, 19, 895-904. [CrossRef]

29. Neutzling, D.M.; Land, A.; Seuring, S.; Nascimento, L.F.M. Linking sustainability oriented innovation to supply chain relationship integration. J. Clean. Prod. 2018, 172, 3448-3458. [CrossRef]

30. Beske, P.; Land, A.; Seuring, S. Sustainable supply chain management practices and dynamic capabilities in the food industry: A critical analysis of the literature. Int. J. Prod. Econ. 2014, 152, 131-143. [CrossRef]

31. Chesbrough, H.W. The era of open innovation. MIT Sloan Manag. Rev. 2003, 44, 35-41.

32. Moore, J.F. Predators and prey: A new ecology of competition. Harv. Bus. Rev. 1993, 71, 75-86. [PubMed]

33. Moore, J.F. The Death of Competition: Leadership and Strategy in the Age of Business Ecosystems; Harper Business: New York, NY, USA, 1996.

34. Adner, R.; Kappor, R. Value creation in innovation ecosystems: How the structure of technological interdependence affects firm performance in new technology generations. Strateg. Manag. J. 2010, 31, 306-333. [CrossRef]

35. Mercan, B.; Goktas, D. Components of innovation ecosystems: A cross-country study. Int. Res. J. Financ. Econ. 2011, 76, 102-112.

36. Adner, R. Ecosystem as structure: An actionable construct for strategy. J. Manag. 2017, 43, 39-58. [CrossRef]

37. Etzkowitz, H.; Leydesdorff, L. The triple helix-university-industry-government relations: A laboratory for knowledge based economic development. Easst Rev. 1995, 14, 11-19.

38. Etzkowitz, H. Innovation in innovation: The triple helix of university-industry-government relations. Stud. Sci. 2003, 42, 293-337. [CrossRef]

39. Carayannis, E.G.; Campbell, D.F.J. Mode 3 and quadruple helix: Towards a 21st century fractal innovation ecosystem. Int. J. Technol. Manag. 2009, 46, 201-234. [CrossRef]

40. Miller, K.; McAdam, R.; McAdam, M. A systematic literature review of university technology transfer from a quadruple helix perspective: Toward a research agenda. RED Manag. 2018, 48, 7-24.

41. Schaffers, H.; Komninos, N.; Pallot, M.; Trousse, B.; Nilsson, M.; Oliveira, A. Smart cities and the future internet: Towards cooperation frameworks for open innovation. In The Future Internet Assembly; Springer: Berlin/Heidelberg, Germany, 2011; pp. 431-446.

42. Schwartz, D.; Bar-El, R. The role of a local industry association as a catalyst for building an innovation ecosystem: An experiment in the state of Ceara in Brazil. Innovation 2015, 17, 383-399. [CrossRef]

43. Mair, J.; Marti, I. Social entrepreneurship research: A source of explanation, prediction, and delight. J. World Bus. 2006, 41, 36-44. [CrossRef]

44. Kanter, R.M. From spare change to real change: The social sector as a beta site from business innovation. Harv. Bus. Rev. 1999, 77, 123-132.

45. Rauter, R.; Globocnik, D.; Perl-Vorbach, E.; Baumgartner, R.J. Open innovation and its effects on economic and sustainability innovation performance. J. Innov. Knowl. 2018, 3. [CrossRef] 
46. Trindade, E.P.; Hinnig, M.P.F.; Da Costa, E.M.; Marques, J.S.; Bastos, R.C.; Yigitcanlar, T. Sustainable development of smart cities: A systematic review of the literature. J. Open Innov. Technol. Mark. Complex. 2017, 3, 11. [CrossRef]

47. Chang, D.L.; Sabatini-Marques, J.; Da Costa, E.M.; Selig, P.M.; Yigitcanlar, T. Knowledge-based, smart and sustainable cities: A provocation for a conceptual framework. J. Open Innov. Technol. Mark. Complex. 2018, 4, 5. [CrossRef]

48. Carrillo, F.J. Knowledge-based development as a new economic culture. J. Open Innov. Technol. Mark. Complex. 2015, 1, 15. [CrossRef]

49. Carayannis, E.G.; Campbell, D.F.J. Triple helix, quadruple helix and quintuple helix and how do knowledge, innovation and the environment relate to each other? A proposed framework for a transdisciplinary analysis of sustainable development and social ecology. Soc. Ecol. Sustain. Dev. 2010, 1, 41-69. [CrossRef]

50. Von Schomberg, R. Towards Responsible Research and Innovation in the Information and Communication Technologies and Security Technologies Fields; Publications Office of the European Union: Luxembourg, 2011.

51. Lubberink, R.; Blok, V.; Van Opherm, J.; Omata, O. Lessons for responsible innovation in the business context: A systematic literature review of responsible, social and sustainable innovation practice. Sustainability 2017, 9, 721. [CrossRef]

52. Eisenhardt, K. Building theories from case study research. Acad. Manag. Rev. 1989, 14, 532-550. [CrossRef]

53. Yin, R.K. Case Study Research: Design and Methods; Sage: Thousand Oaks, CA, USA, 2003.

54. Heineken. Available online: https://www.theheinekencompany.com/ (accessed on 30 April 2019).

55. BMW Group. Available online: https://www.bmwgroup.com/ (accessed on 30 April 2019).

56. P\&G. Available online: https://www.pg.com/ (accessed on 30 April 2019).

57. Cloyd, G.; Euchner, J. Building open innovation at P\&G: An interview with Gil Cloyd. Res. Technol. Manag. 2012, 14-19. [CrossRef]

58. Ozkan, N.N. An example of open innovation: P\&G. Procedia Soc. Behav. Sci. 2015, 195, 1496-1502.

59. Rockstrom, J. A safe operating space for humanity. Nature 2009, 461, 472. [CrossRef] [PubMed]

60. Parmar, B.L.; Freeman, R.E.; Harrison, J.; Purnell, A.C.; De Colle, S. Stakeholder theory: The state of the art. Acad. Manag. Ann. 2010, 3, 403-445. [CrossRef]

61. Lele, S. Rethinking sustainable development. Curr. Hist. 2013, 112, 311-316.

62. McCarthy, L.; Touboulic, A.; Matthews, L. Voiceless but empowered farmers in corporate supply chains: Contradictory imagery and instrumental approach to empowerment. Organization 2018, 25, 609-635. [CrossRef]

63. Khalid, R.U.; Seuring, S.; Beske, P.; Land, A.; Yawar, S.A.; Wagner, R. Putting sustainable supply chain management into base of the pyramid research. Supply Chain Manag. Int. J. 2015, 20, 681-696. [CrossRef]

64. Siyanbola, W.; Abiodum, E.; Adebowale, B.A.; Olumuyiwa, O. Innovation Systems and Capabilities in Developing Regions: Concepts, Issues, Cases; Routledge: New York, NY, USA, 2016. 